\title{
REVIEW
}

\section{Ghrelin in Pathological Conditions}

\author{
SIMONI A. KATERGARI, ATHANASIOS MILOUSIS, OLGA PAGONOPOULOU, BYRON ASIMAKOPOULOS \\ AND NIKOS K. NIKOLETTOS
}

Laboratory of Physiology, Medical School, Democritus University of Thrace, Alexandroupolis, Greece

\begin{abstract}
The recently identified gastric hormone ghrelin was initially described as a natural Growth Hormone Secretagogue Receptor ligand. Apart from ghrelin's first discovered action, which was the stimulation of Growth Hormone release, implications for many other functions have been reported. It seems that ghrelin exhibits an important role in conditions related to processes regulating nutrition, body composition and growth, as well as heart, liver, thyroid or kidney dysfunction. In this review, current available knowledge about ghrelin's role in various pathological conditions is presented.
\end{abstract}

Key words: Ghrelin, Pathological conditions

(Endocrine Journal 55: 439-453, 2008)

THE gastric hormone ghrelin was first identified as an endogenous ligand for the former orphan receptor Growth Hormone Secretagogue Receptor 1a (GHS-R) [1-4]. Its discovery is an example of reverse pharmacology, meaning that it started with the synthesis of analogues [Growth Hormone-Releasing Peptides (GHRPs)] and Growth Hormone Secretagogues (GHSs) $[5,6]$ and it ended with the discovery of a natural ligand [7] via the discovery of a natural receptor [2]. GHS-R is a classical G-protein coupled receptor, consists of 366 amino acids and it was found to contain seven putative alpha-helical membrane spanning segments and three intracellular and extracellular loops. It is distributed widely in the anterior pituitary and in both hypothalamic and non-hypothalamic regions. Surprisingly, higher GHS-R stimulation activity was also found in stomach extracts by Kojima et al., who were also able to identify its purified endogenous ligand, ghrelin [7]. The term "ghrelin" contains "ghre" as an etymological root for "growth" in many languages [8]. "GH" and "relin" also represent an abbreviation

Received: January 21, 2007

Accepted: August 7, 2007

Correspondence to: Professor Nikos K. NIKOLETTOS, Laboratory of Physiology, University Campus, Dragana, 68100, Alexandroupolis, Greece for "growth-hormone-release", a characteristic effect of ghrelin [3,9].

Human ghrelin gene is located on chromosome 3 and consists of 4 exons and 3 introns. Human and rat genes that encode ghrelin are similar to the ones in the mouse [10]. The product of the gene transcription is processed by alternative splicing to yield two different mature mRNAs, which produce the ghrelin precursor and des-Gln 14-ghrelin. Both these two peptides are biologically active, although the presence of lower amounts of des-Gln 14-ghrelin in the human stomach suggests that ghrelin is the major active form [3].

Ghrelin precursors, as discovered in rats and humans, consist of 117 amino acids [11] and the ghrelin sequence immediately follows the signal peptide. Ghrelin is a 28 amino acid peptide with an n-octanoylation at Ser3. This n-octanoyl modification is needed in order to keep ghrelin functional [11].

Also, from the ghrelin precursor protein derives obestatin, a recently identified 23 -amino acid peptide which has originally been described to suppress food intake, inhibit jejunal contraction and decrease body weight gain [12]. Furthermore, four other minor ghrelin-derived molecules have been isolated from rat stomach including octanoyl ghrelin-(1-27), decanoyl ghrelin, decanoyl ghrelin-(1-27) and decenoyl ghrelin. All these molecular forms of ghrelin were also found 
in human plasma and stomach [13].

Ghrelin mRNA is expressed in several tissues. In the stomach, ghrelin-containing cells are found to be a distinct endocrine cell type in the submucosal layer of the stomach, known as X/A like cells, that represent a major endocrine population in the oxyntic mucosa [14]. These cells contain round, compact, electrondense granules and are filled with ghrelin [15]. The fact that adult human plasma ghrelin concentrations

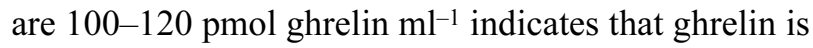
secreted into blood vessels, to circulate throughout the whole body [15]. Ghrelin is also expressed in other tissues, such as hypothalamus [7], pituitary [16], heart [17], the small and large intestine [15], placenta [18], pancreas [19], kidney [20], testes [21], lymphocytes [22].

Apart from GH-releasing effects there is a recent large quantity of information on ghrelin's action including hypothalamic activities [23], influence on the pituitary-gonadal axis [24], stimulation of appetite [11, $25,26]$, influence on sleep [27, 28] and behavior [29], control of gastric motility [30] and acid secretion [31, 32]. It also exhibits action on the cardiovascular system, [33] the immune system [22] and on neoplastic cells [34] and induces adiposity [25]. Ghrelin levels change significantly throughout development. The highest levels are found during early postnatal life, when growth hormone begins to exert its effects on growth and important changes in food intake occur [35].

In order to determine the physiological role of ghrelin genetic studies have been carried out. Ablation of ghrelin resulted in no significant difference in size, growth rate, food intake, body composition and reproduction between ghrelin-null (Ghrl-/-) mice and wildtype littermates [36]. Exogenous ghrelin stimulated appetite in both Ghrl-/- and wild-type mice [36]. It has also been reported that male Ghrl-/- mice exhibited no rapid weight gain induced by early exposure to a high-fat diet 3 weeks after weaning [37].

Given this wide spectrum of biological activities, it is evident that the discovery of ghrelin opened many new perspectives within neuroendocrine and metabolic research [38, 39].

In this review, ghrelin is examined in relation to various clinical conditions, aiming to find out whether ghrelin plays a role for or against them.

\section{Ghrelin and Growth Hormone release}

The pattern of GH secretion is complex and is regulated positively by Growth Hormone Releasing Hormone (GHRH) and negatively by somatostatin (SS), two neurohormones that interact functionally at both hypothalamic and pituitary levels, and whose interactions are responsible for the pulsatile GH release pattern in mammals [40]. Ghrelin, whose first discovered action was the stimulation of GH release [41] seems to act either by directly activating the Central Nervous System receptors located inside or outside the blood-brain barrier or by peripheral activation of the vagal nervous system [42].

There is some evidence indicating the regulating role of ghrelin in GH release [41, 43]. It has been reported that GHRH infusion increased pituitary levels of ghrelin RNA and that, decreased hypothalamic secretion of GHRH, caused decreased pituitary ghrelin expression, indicating that pituitary ghrelin expression is GHRH dependent [44]. Furthermore, it seems that ghrelin-induced GH secretion is exerted via a hypothalamic point of action, as suggested by a recent report in which exogenous ghrelin was unable to significantly increase $\mathrm{GH}$ release in patients with hypothalamic organic lesions, suggesting that the GH response to ghrelin in vivo requires an intact endogenous GHRH system [45]. Also, an undamaged GHSR system seems to be important for ghrelin to exert its $\mathrm{GH}-$ releasing and appetite-stimulating actions [46, 47].

Ghrelin levels seem to differ between the two sexes, as basal ghrelin concentrations in women during the late follicular stage are higher than those of men [48], explaining, at least in part, the differences in GH secretion between the two sexes.

It has been proposed that ghrelin rejuvenates the GH/IGF-1 axis. Chronic administration of either the exogenous GHSs, or ghrelin, has been reported to elevate the lowered GH levels due to ageing [49]. On the other hand, ghrelin levels are lowered in acromegaly, when GH levels are elevated [50]. These two findings indicate the existence of a possible feedback effect of $\mathrm{GH}$ upon ghrelin. Furthermore, the pattern of ghrelin fluctuations is similar to that of $\mathrm{GH}$ and Insulin like Growth Factor 1 (IGF-1) secretion [4, 51].

GHRH seems to be the primary stimulator of GH secretion and ghrelin plus GHRH seem to be more effective than either peptide alone upon GH secretion [52]. Furthermore, somatostatin and metabolic compounds 
(glucose or free fatty acids) have no inhibitory effect on ghrelin-induced GH release, unlike GHRH-induced GH release, which is restrained by somatostatin [53].

It seems that there is a reduction in the number and size of GH-immunoreactive cells in aged human pituitary [54] a state in which GH secretion is impaired [40]. Ghrelin administration might be more effective in treating GH-deficiency in states, such as aging, than administration of either GH or GHRH alone [40].

\section{Ghrelin and pathological conditions of Growth Hormone hypersecretion or deficiency}

In patients with active acromegaly, elevated $\mathrm{GH}$ and IGF-1 levels cause an impaired inhibition in glucose uptake and stimulation in glucose output, representing a state of insulin resistance $[50,55,56]$. Fasting serum ghrelin levels have been reported lower than $[50,55$, 57] or similar to healthy controls $[65,66]$ in patients with active acromegaly. Ghrelin levels in acromegaly have been reported negatively correlated to IGF-1 [59] and low basal levels of ghrelin are not further reduced during the Oral Glucose Tolerance Test (OGTT) [55], implying that ghrelin secretion depends on insulin resistance induced by GH, together with some degree of a putative GH-IGF-1 negative feedback control [59]. Furthermore, ghrelin seems to affect both pituitary and Gastro-Entero-Pancreatic hormone secretion in patients with acromegaly, as in normal subjects [60].

Ghrelin is expressed in many types of pituitary adenomas, including those in patients with acromegaly, enhancing the development of adenoma cells via autocrine and/or paracrine pathways [61].

Treatment of acromegaly, which consists of administration of Growth Hormone Receptor (GHR) antagonists [62-70], somatostatin analogues (octreotide and lanreotide) $[50,58,71-73]$ or surgical treatment $[50$, $57,58,74]$, results in diverse ghrelin levels. Treatment with octreotide has successfully suppressed previously elevated GH and IGF-1 levels [50, 71-73] and ghrelin secretion [45] in acromegalics. Surgical transsphenoidal removal of a GH-secreting tumor has also been used in order to eliminate the cause of GH excess and is followed by an improvement of insulin sensitivity $[50,57,74]$. Ghrelin levels have been reported to increase after successful transsphenoidal surgery followed by normalization of GH and IGF-1 [50, 57, 58], suggesting a preoperative ghrelin suppression caused by GH/IGF-1 hypersecretion. In contrast, treatment with octreotide seems to cause a persistent suppression in serum ghrelin levels in acromegalic patients $[50,57$, $58,61]$, as in healthy subjects $[61,75]$ possibly via a direct effect of octreotide on ghrelin-producing gastric cells [50]. Given the fact that the diagnosis and the post-treatment evaluation of the disease activity, based on the post-glucose nadir value or GH and IGF-1 levels have some limitations $[56,74]$, ghrelin levels might be useful for diagnostic purposes [74] or for posttreatment assessment of cure.

Patients with Growth Hormone Defeciency (GHD) show lower levels of GH and IGF-I [59, 76]. Plasma ghrelin levels in GHD patients have been reported similar to [59, 76] or lower [77] than those of healthy, Body Mass Index (BMI) - matched subjects. Ghrelin was found not to be correlated to either GH or IGF-1 in GHD patients $[48,59,76]$. However, in GHD, ghrelin was found inversely correlated with waist circumference and waist-to-hip ratio, suggesting that ghrelin concentrations are influenced by body fat distribution in both normal and GHD subjects [76].

Another syndrome usually characterized by GH deficiency, hypogonadotropic hypogondism, obesity and hyperphagia is the Prader-Willi Syndrome (PWS), a complex genetic disorder caused by lack of expression of paternally inherited imprinted genes on chromosome 15q11-q13 [78]. Studied in children and in adults with PWS fasting ghrelin has been reported to be higher than in BMI and percent body fat-matched controls $[79,80]$. Furthermore, in children with PWS, ghrelin levels were decreased after a meal, indicating that the regulation of meal-induced ghrelin suppression is still operative during childhood [81], although such a decrease postprandially is not observed in PWS adults [80].

Hexarelin, a GHS [82, 83], GHRH [52, 63] and human recombinant $\mathrm{GH}$ (rhGH) [77, 84], have long been used for treatment of GHD. One year of treatment with rhGH in GHD adults resulted in an increase in the previously low fasting ghrelin levels, related possibly to the reduction of BMI and percentage of body fat accompanying rhGH therapy. On the other hand, short-term (7 days) treatment of GHD with rhGH resulted, as expected, in increased levels of IGF-1 and further decrease in ghrelin's levels, possibly due to an inhibitory feedback between GH/IGF-1 and ghrelin [77].

More experimental data are needed in order to clarify the exact impact of ghrelin on GH/IGF-1 axis, and 
therefore propose a role for ghrelin in diagnostic procedures or treatment of GHD.

\section{Ghrelin and Obesity}

The growing prevalence of obesity and eating disorders has led to an increasing interest to investigate the mechanisms involved in energy homeostasis and food intake. A complex physiological system exists to balance energy expenditure, composed of both afferent signals and efferent effectors [85]. Ghrelin was found to be one of the most powerful orexigenic and adipogenic agents known in mammalian physiology [11, 25], stimulating appetite and increasing food intake when administered intravenously in healthy humans [26]. Ghrelin functions as an orexigenic signal from the gut to the brain [86], is expressed mainly in the stomach and its immunoreactivity has also been found in the arcuate nucleus of the hypothalamus [87]. Plasma ghrelin concentrations rise progressively during fasting and fall to a nadir within an hour of eating [86, 88]. Its effect seems to be mediated via stimulation of a population of arcuate nucleus neurons [87], which co expresses two orexigenic peptides: neuropeptide $\mathrm{Y}$ and agouti-related protein. The nucleus is located at the base of the hypothalamus on both sides of the third ventricle and due to the weak blood-brain barrier in this region, it is exposed to peripheral signals such as circulating adrenal and gonadal steroids and large peptides such as leptin and insulin [86, 89].

Ghrelin secretion is up-regulated under conditions of negative energy balance and down-regulated in the setting of positive energy balance, and is negatively correlated with BMI, body fat mass, adipocyte size, plasma insulin levels, plasma glucose levels and plasma leptin levels [51]. Interestingly, the ratio of fasting ghrelin to obestatin was positively correlated to BMI and was found higher in obese than in controls, despite the fact that it decreased in both groups postprandially, suggesting a possible involvement of high preprandial ratio in the pathophysiology of obesity [90].

The effect of ghrelin on metabolism seems to be opposite to that of leptin [3, 7, 91-93]. In obesity, ghrelin plasma levels are decreased, possibly indicating physiological adaptation to positive energy balance rather than an involvement in the etiology of obesity [94-97], although a blunting in the nocturnal rise in ghrelin concentrations in obese subjects might be an important element in obesity biology [96].
Many efforts are currently being made towards the modulation of the bioavailability of an endogenous orexigenic factor, such as ghrelin, in order to treat obesity. In vitro generated biostable RNA-based compounds that specifically bind n-octanoyl ghrelin have been used successfully in experimental animal models, aiming to inhibit ghrelin-mediated GHS-receptor activation [98]. Furthermore, vaccination of rats with ghrelin immunoconjugates resulted in decreased feed efficiency and body weight gain and reduction of body fat [99].

\section{Ghrelin and Eating Disorders}

A number of experimental data have clarified that nutritional conditions regulate GH secretion $[23,51]$ and indeed undernutrition and fasting are associated with enhanced GH secretion in human, whereas over nutrition, exemplified by obesity, is characterized by suppressed GH release [94]. Anorexia nervosa (AN) is a state of chronic under nutrition in which GH secretion is highly disordered and, on the whole, markedly enhanced.

Mean fasting levels of plasma ghrelin in both subtypes of AN patients, the dietary restricting form (AN$\mathrm{R})$ and the binge-eating/purging form (AN-BP), were found significantly elevated compared to healthy, BMI-matched, subjects [97, 100]. Both BMI and the presence or absence of binge-eating/purging seems to have some influence on fasting plasma ghrelin levels in these patients. Fasting ghrelin levels in AN-BP patients were reported to be significantly higher than that in AN-R ones and plasma ghrelin concentrations in both forms of the illness were negatively correlated with BMI [101]. Absence of influence of high plasma ghrelin concentrations on feeding in patients with AN could suggest a lack of sensitivity to circulating ghrelin. It seems that up-regulation of ghrelin under conditions of negative energy balance may represent a negative feedback mechanism in order to maintain energy balance [97]. For all that, exogenous ghrelin administration is unlikely to be effective as a single appetite stimulator for this patient group [102].

On the other hand, ghrelin levels in subjects with bulimia nervosa $(\mathrm{BN})$, an eating disorder characterized by habitual abnormal binge eating behaviour, have been reported to be elevated compared to healthy controls [103], possibly inducing hyperphagia in BN patients. Ghrelin levels in this patient group have been 
reported negatively correlated to BMI [103-105] and other nutritional parameters, such as percent body fat [105]. A relationship between plasma ghrelin levels and habitual binge-eating and purging seems difficult to be established. Ghrelin in BN purging type (BN-P) has been reported higher than in both $\mathrm{BN}$-non purging (BN-NP) and healthy controls [105]. In addition, both $\mathrm{BN}-\mathrm{P}$ and AN-BP subjects have shown significant correlation among plasma ghrelin values, frequencies of binge-purge cycles and serum amylase values [105]. On the other hand, in a recent report, women with binge-eating and purging behaviour had lower ghrelin levels than women with AN-R [104]. Either ghrelin levels are influenced by habitual binge/puging or ghrelin concentrations simply reflect the nutritional status and energy imbalance regarded in these forms of eating disorders.

Studies conducted to determine the degree of heritability of eating disorders have yielded some interesting results, showing either genetic susceptibility to AN [106] or BN-P [107, 108], or no correlation of any of the ghrelin gene variants with eating disorders [109]. The dissimilarity observed in various studies including ghrelin gene polymorphisms, may possibly be attributed to different study populations.

\section{Ghrelin and Diabetes}

The influence of ghrelin on insulin secretion has been studied extensively. There are conflicting results from animal studies, suggesting a stimulatory $[19,110$, $111]$, or inhibitory $[112,113]$ effect of ghrelin on insulin. In humans, studies demonstrate that ghrelin exerts modulatory action on insulin secretion and glucose metabolism [113], suggesting a negative association between ghrelin and insulin [88, 114-116]. Intravenous administration of glucose and insulin failed to suppress serum ghrelin, contrary to oral meal effect, suggesting that, besides insulin, other referring signals from the gastrointestinal track possibly interfere with the postprandial ghrelin suppression [117].

Basal ghrelin levels were found to be decreased compared with healthy subjects in children with newly diagnosed Type 1 Diabetes Mellitus (T1DM), both at the time of diagnosis and after 1-4 months of insulin treatment [118]. Moreover, it has been suggested that basal insulin secretion is essential for meal-induced ghrelin suppression, as shown in a study comparing postprandial ghrelin levels in patients with T1DM given intravenously prandial doses, basal doses or no insulin during meal intake [119].

Low plasma ghrelin has been associated with insulin resistance, hypertension and Type 2 Diabetes Mellitus (T2DM) [120]. In T2DM subjects, basal ghrelin concentrations were found to be lower compared to normal and to obese normoinsulinemic subjects, whilst postprandial ghrelin suppression was attenuated in both diabetics and hyperinsulinemic patients [121].

It has also been shown that among patients with T2DM, obese patients had lower and lean patients' higher fasting plasma ghrelin concentrations than normal-weight patients. Fasting plasma ghrelin concentration was negatively correlated with BMI in both nondiabetic and diabetic patients [89].

Mice lacking leptin (ob/ob) are hyperphagic, obese and hyperglycemic. Ablation of ghrelin in ob/ob mice resulted in no reduction of hyperphagia and obesity although the hyperglycemia observed in ob/ob mice was reduced [122]. Deletion of ghrelin caused an increase in insulin secretion in response to glucose challenge and augmented peripheral insulin sensitivity [122], implying that, in animal model, ghrelin seems to contribute to the regulation of insulin secretion and insulin sensitivity.

\section{Ghrelin and Cardiovascular System}

Ghrelin has been demonstrated to exert cardiac effects in both animal models [123-127] and in humans $[6-8,128]$. Ghrelin administration seem to excert beneficial cardiac effects on isoproterenol-induced myocardial injury $[124,125]$ and negative inotropic effect on guinea pig papillary muscle [126]. Furthermore, in rat hearts subjected to ischemia followed by reperfusion, both ghrelin and the synthetic peptidyl GHS hexarelin, significantly reduced infract size, whilst desacylated ghrelin administration had no significant effect on ischemic injury [123]. Furthermore, ghrelin-treated group of rats after myocardial infraction showed a greater increase in body weight, a significantly higher cardiac output, increased diastolic thickness of the non-infracted posterior wall and an inhibited Left Ventricular (LV) enlargement compared to the group given placebo [127].

Ghrelin and ghrelin receptor are expressed in human isolated arteries, veins and vascular smooth muscle cells and cardiomyocytes [129]. Furthermore, both ghrelin and des-octanoyl ghrelin showed a vasodilator 
potency and efficacy in reversing ET-1 induced vasoconstriction [129].

Beneficial heamodynamic effects of ghrelin in healthy humans via reducing cardiac afterload and increasing cardiac output have been demonstrated [130, 131], including a decrease in mean arterial pressure (MAP), without a significant change in heart rate, increase in cardiac index and stroke volume index and decrease in systemic vascular resistance [130] and also an increase in left ventricular (LV) ejection fraction in a dose-dependent manner, without significantly altering circulating levels of corticotropin, cortisol, IGF-1, noradrenaline or adrenaline [131].

In patients with Chronic Heart Failure (CHF) plasma ghrelin levels were not significantly different compared to healthy subjects [132]. However, patients with cardiac cachexia (body weight loss and muscle wasting in end-stage CHF) [128] had significantly higher ghrelin levels than those without cachexia, and those levels were negatively correlated with BMI and positively with GH and Tumor Necrosis Factor-a, possibly indicating that increased ghrelin levels in these patients may have a compensatory role under conditions of anabolic/catabolic imbalance [132]. Ghrelin treatment in this patient group resulted in significant decrease in MAP, and increased cardiac index and stroke volume index, potentially through arterial vasodilatation and reduction of cardiac afterload [133] and improved muscle wasting and increased peak workload and peak oxygen consumption [134]. In addition, plasma norepinephrine levels were significantly decreased by ghrelin administration implying that beneficial effects of ghrelin on cardiac performance may be due to inhibitory effects of ghrelin on sympathetic nerve activity [134].

Taken together, current data suggest that ghrelin might be used as a therapeutic potential in the treatment of CHF and cardiac cachexia [135], although more studies are needed to further clarify in detail its mechanisms of action.

\section{Ghrelin and Liver}

Several studies have been carried out in order to elucidate the role of ghrelin in liver disease. Interest has been so far focused on ghrelin levels in chronic liver disease (CLD), Hepatocellular Carcinoma (HCC) and non-alcoholic fatty liver disease (NAFLD).

Ghrelin serum levels were found elevated in patients with CLD compared with healthy controls [136] and were not correlated to neither the grade of liver dysfunction or to the etiology of CLD (viral, biliary, alcohol and others). However, clinical parameters associated with deterioration of CLD such as gastrointestinal bleeding, ascites and encephalopathy as well as anemia, inflammatory markers, hypoglycemia and renal dysfunction were found to have a positive correlation with ghrelin levels [136]. Also, there was no correlation found between hypertensive gastropathy, gastric fundus varices, portal hypertension and esophageal varices and ghrelin levels, possibly because X/A like cells resist to lesions of the stomach mucosa [137]. Finally, ghrelin was not associated with BMI, possibly as BMI may not be a suitable index for cachexia in CLD patients because of the high prevalence of ascites and peripheral edema [136].

Ghrelin levels and levels of alpha-fetoprotein (AFP) have been reported to be inversely correlated in HCC patients. It remains unclear whether low ghrelin levels in HCC are responsible for some clinical symptoms of advanced carcinomas, such as the decrease in appetite and food intake, and negative energy balance [136] GHS-R has been reported to be expressed in human hepatoma cells [138]. Ghrelin induces an upregulation of insulin-induced activities in these cells, such as phosphorylation of Insulin Receptor Substrate-1 (IRS1), mitogen-activated protein kinase activity and cell proliferation, possibly implying ghrelin's mitogenic potential in hepatoma cells [138].

The role of ghrelin in NAFLD is still unclear. In a study, low ghrelin serum levels were found in NAFLD patients [137] while in another study it was demonstrated that low ghrelin levels could not be attributed to small intestinal bacterial activity [139], which is encountered commonly in non-alcoholic steatohepatitis. In addition, ghrelin levels were significantly correlated with Homeostasis Model Assessment index (HOMA- ${ }_{I R}$ ) in both healthy and NAFLD patients [137].

\section{Ghrelin and Renal Failure}

Using specific radioimmunoassays, plasma ghrelin and desacyl-ghrelin were measured in patients with mild-to-severe renal failure and were compared to samples of healthy subjects. Plasma ghrelin plus desacyl-ghrelin seem to increase in proportion to the severity of renal failure and correlate with fat mass, plasma insulin and serum leptin levels [140, 141] and inverse- 
ly correlated to glomelular filtration rate (GFR) and to BMI [142]. Recent studies in rodents demonstrated that ghrelin gene is expressed in glomerulus and renal cells [20], as well as in the epithelium of the distal tubules [143].

Approximately one-fifth of ghrelin-like immunoreactivity is detected in the urine compared with the plasma ghrelin concentration in healthy subjects, suggesting that ghrelin is filtered from the blood or actively secreted into the urine or that the peptide is more stable in the urine than in the circulation [140]. In addition, bilateral nephrectomy and heminephrectomy in mice cause an increase in plasma total ghrelin. However, since nephrectomy does not increase steady state ghrelin contents and ghrelin mRNA levels in the stomach, it seems that increased ghrelin in renal failure results from decreased clearance or degradation in the kidney [140].

It has been shown that approximately half of the plasma total ghrelin (ghrelin plus desacyl-ghrelin), as well as almost ninety percent of $\mathrm{GH}$, are removed from the blood by a single course of hemodialysis. In addition, ghrelin levels were found lower in patients on PD than the predialysis and the HD ones, suggesting a possible explanation for the anorexia presented most often in patients on PD [144].

\section{Ghrelin and Thyroid Disorders}

Hyperthyroid patients have been reported to have increased appetite and food intake, although the underlying mechanism is not well established [145]. Studies have revealed that ghrelin levels are reduced in hyperthyroidism and become normalized by medical antithyroid treatment $[146,147]$. This indicates that hyperphagia associated with hyperthyroidism is possibly not mediated via circulating ghrelin. Excess of thyroid hormones have been suggested to regulate circulating ghrelin levels. It has also been shown that the euglycemic hyperinsulinemic clamp suppresses circulating ghrelin levels compared with fasting ones regardless of thyroid status [146].

In addition, ghrelin levels in hypothyroid patients have been reported similar to those of healthy subjects [147], although in animal model of hypothyroidism, ghrelin was found increased [148].

It has been demonstrated that ghrelin is expressed in fetal but not in infant or adult thyroid, and is reexpressed in tumors. It seems that there are ghrelin receptors other than GHS-Rs in normal and neoplastic adult thyroid, as ghrelin-binding sites may be detected in the absence of the specific GHS-R mRNA. Moreover, it seems that ghrelin possesses anti-proliferative properties in thyroid carcinoma cells lines in both undifferentiated and differentiated tumor cell lines, suggesting a possible role of ghrelin in regulating tumor growth [149].

\section{Ghrelin and Biliopancreatic Diversion, $R$-en-Y Gastric Bypass, Gastric Banding}

Basal ghrelin levels are reported to decrease in obese subjects [51]. Several surgical methods have been used to induce weight loss [150-157]. The mechanisms that lead to weight loss after surgical procedures aiming to weight reduction in morbidly obese subjects have been studied extensively. Three types of surgical methods are usually used for weight loss: laparoscopic and laparoscopic adjustable silicone gastric banding (ASGB).

The acute decrease of plasma ghrelin in subjects after biliopancreatic diversion (BPD), was followed by an increase in ghrelin levels, two [150] and twelve [158] months postoperatively, although BMI and HOMA $_{\text {IR }}$ decreased [151]. HOMA- ${ }_{\text {IR }}$ was negatively correlated to circulating ghrelin, indicating that ghrelin increased levels postoperatively could be involved in the improvement of insulin sensitivity [151].

In contrast, studied in patients post- Roux-en-Y gastric bypass (RYGB), ghrelin levels have been reported to be lower than the pre-operative ones for a longer period of time [153, 157]. Moreover, the 24-hour ghrelin profile in patients after RYGB was reported lower, compared to patients with diet-induced weight loss despite the greater percent of weight loss in the postRYGB group. Furthermore, meal-related fluctuations and diurnal rhythm of ghrelin, while present in the dieting group, were absent in the post-operative one. It seems reasonable that the markedly suppressed ghrelin levels after RYGB might contribute to the long-term weight-reducing effect of the procedure [157].

In order to compare the effects of different surgical procedures, Plasma ghrelin was determined and found increased after weight loss 24 months following ASGB compared to baseline, preoperative levels, in contrast to ghrelin levels after RYGB, although weight decreased less in post-ASGB than in RYGB subjects 
[155], explaining, in part, the more sustained weight loss observed post-RYGB. Moreover, no meal-related changes in plasma ghrelin were observed in post-RYGB and post-ASGB groups compared to not operated controls. These findings suggest that each method leads to weight loss by a different mechanism involving ghrelin [156].

\section{Ghrelin and Cancer}

Expression of ghrelin and its functional receptor has been detected in different types of cancer, especially hormone-dependent cancers of the prostate [159, 160], breast [34] and ovarian/endometrial systems [160], and in normal human testis and testicular tumors [161]. The presence of ghrelin and GHS-R in neoplastic cell lines suggests a potential role in regulating cancer cell proliferation through autocrine/paracrine pathways.

Ghrelin production has been detected in cancer cell lines of the stomach, intestine $[162,163]$, and pancreas [164], where it increased proliferation, motility and invasiveness of pancreatic adenocarcinoma cell lines, In the liver, ghrelin is reported to up-regulate several insulin-induced activities, including mitogen-activated protein kinase activity and cell proliferation [165].

Ghrelin is produced in both normal and adenomatous human pituitary $[166,167]$. The presence of ghrelin mRNA and GHS-R mRNA in pituitary adenomas also indicates that pituitary adenoma-produced ghrelin may contribute to the development of adenoma cells in an autocrine/paracrine manner [164]. Ghrelin has been shown to stimulate proliferation in rat pituitary cell lines and this effect is inhibited by Mitogen-Activated Protein Kinase (MAPK), tyrosine kinase and protein kinase C inhibitors [167, 165]. Activation of MAPKs has been observed in several tumor cell lines [166]. It is noteworthy that normal or benign and malignant tissues express the components of the ghrelin GHS-R axis [160]. An evaluation of the potential use of ghrelin as diagnostic markers or as targets for anti-cancer treatment could therefore be of therapeutic importance.

Studies of the expression of ghrelin in the thyroid gland showed that ghrelin is produced in fetal thyroid and follicular tumors [166], as well as by human thyroid parafollicular carcinoma cell lines [168], and by medullary thyroid carcinoma and thyroid $\mathrm{C}$ cells [169]. Ghrelin was found to inhibit thyroid cell prolif- eration of thyroid carcinoma cell lines, in vitro, dosedependently and synthetic GHSs were found to cause a significant inhibition of cell proliferation on cell lines derived from follicular thyroid cancer cells [170].

Elevated ghrelin levels have been reported in patients with lung cancer cachexia, compared to patients with lung cancer without cachexia. Ghrelin levels increased in patients with anorexia following chemotherapy, perhaps representing a compensatory mechanism for the catabolic-anabolic imbalance in cachectic patients [171]. In addition, in animal model of cancer cachexia, plasma ghrelin concentrations increased with the progression of cachexia [172]. However, synthetic peptidyl GHSs exhibited an antiproliferative effect on human CALU-1 lung cancer cells [171]. Since the results of the existing studies are conflicting, further ones are needed to elucidate the role of ghrelin in the development of both lung and thyroid cancer.

\section{Conclusion}

Ghrelin is a newly identified hormone and new aspects of its function are discovered nearly on daily

Table 1. Basal ghrelin levels in pathological conditions compared to healthy subjects

\begin{tabular}{ll}
\hline \multicolumn{1}{c}{ Disease } & \multicolumn{1}{c}{ Basal Ghrelin Levels } \\
& Compared to Healthy Subjects \\
\hline Acromegaly & $\downarrow / \leftrightarrow$ \\
Prader-Willi Syndrome & $\uparrow$ \\
GH deficiency & $\downarrow / \leftrightarrow$ \\
Obesity & $\downarrow$ \\
Anorexia Nervosa & $\uparrow$ \\
Bulimia Nervosa & $\uparrow$ \\
Diabetes & $\uparrow$ in lean T2DM \\
& $\downarrow$ in obese T2DM \\
& $\downarrow$ in T1DM \\
Cardiovascular Disease & $\leftrightarrow$ in CHF without cachexia \\
& $\uparrow$ in CHF cachexia \\
Liver Disease & $\uparrow$ in CLD \\
& $\downarrow$ in HCC and NAFLD \\
Renal Failure & $\uparrow$ \\
Thyroid disorders & $\downarrow$ in hyperthyroidism \\
& $\leftrightarrow$ in hypothyroid \\
Surgical interventions to & $\downarrow$ shortly after BPD, \\
$\quad$ reduce weight & $\uparrow$ long-term after BPD \\
& $\downarrow$ after RYGP \\
& $\uparrow$ after ASGB \\
Cancer & $\uparrow$ in cancer cachexia \\
\hline
\end{tabular}

$\uparrow$ : Increased levels, $\downarrow$ : decreased levels, $\leftrightarrow$ : no change 
basis. Ghrelin represents a crucial endocrine link connecting physiological process regulating nutrition, body composition, and growth [38]. The recent discovery of obestatin [12], may lead to elucidate the terms of energy homeostasis. Taking into account that ghrelin is related to a great amount of pathological conditions (summarized in Table 1), including heart, liver, thyroid and kidney disfunction, ghrelin's pathophysiological role and its therapeutic implications remain to be fully investigated.

\section{References}

1. Howard AD, Feighner SD, Cully DF, et al. (1996) A receptor in pituitary and hypothalamus that functions in growth hormone release. Science 273: 974-977.

2. Smith RG, Van der Ploeg LH, Howard AD, et al. (1997) Peptidomimetic regulation of growth hormone secretion. Endocr Rev 18: 621-645.

3. Kojima M, Hosoda H, Matsuo H, Kangawa K (2001) Ghrelin: discovery of the natural endogenous ligand for the growth hormone secretagogue receptor. Trends in Endocrinol Metabol 12: 118-122.

4. Dieguez C, Casanueva FF (2000) Ghrelin: a step forward in the understanding of somatotroph cell function and growth regulation. Eur J Endocrinol 142: 413417.

5. Momany FA, Bowers CY, Reynolds GA, et al. (1981) Design, synthesis and biological activity of peptides which release growth hormone in vitro. Endocrinology 108: 31-39.

6. Bowers CY (1998) Growth hormone-releasing peptide (GHRP). Cell Molec Life Sci 54: 1316-1329.

7. Kojima M, Hosoda H, Date Y, et al. (1999) Ghrelin is a growth-hormone-releasing acylated peptide from stomach. Nature 402: 656-660.

8. Horvath TL, Diano S, Sotonyi P, Heiman M, Tschop M (2001)Minireview: ghrelin and the regulation of energy balance-a hypothalamic perspective. Endocrinology 142: 4163-4169.

9. Hosoda H, Kojima M, Matsuo H, Kangawa K (2000) Purification and characterization of rat des-Gln14Ghrelin, a second endogenous ligand for the growth hormone secretagogue receptor. $J$ Biol Chem 275: 1995-2000.

10. Wajnranch MP, Ten IS, Gertner JM, Leibel RL (2000) Genomic organization of human ghrelin gene. $J$ of Med Gen 1: 231-233.

11. Waren AM, Small CJ, Ward HL, et al. (2000) The novel hypothalamic peptide ghrelin stimulates food intake and growth hormone secretion. Endocrinology 141: 4325-4328.

12. Zhang JV, Ren PG, Avsian-Kretchmer O, et al. (2005) Obestatin, a peptide encoded by the ghrelin gene, opposes ghrelin's effects on food intake. Science 310: 996-999.

13. Hosoda H, Kojima M, Mizushima T, Shimizu S and Kangawa K (2003) Structural Divergence of Human
Ghrelin. identification of multiple ghrelin-derived molecules produced by post-translational processing. $J$ Biol Chem 278: 64-70.

14. Dornonville de la Cour C, Bjorkqvist M, Sandvik AK, et al. (2001) A-like cells in the rat stomach contain ghrelin and do not operate under gastrin control. Regulat Peptides 99: 141-150.

15. Date Y, Kojima M, Hosoda H, et al. (2000) Ghrelin, a novel growth hormone-releasing acylated peptide, is synthesized in a distinct endocrine cell type in the gastrointestinal tracts of rats and humans. Endocrinology 141: 4255-4261.

16. Korbonits M, Kojima M, Kangawa K, Grossman AB (2001) Presence of ghrelin in normal and adenomatous human pituitary. Endocrine 14: 101-104.

17. Baldanzi G, Filigheddu N, Cutrupi S, et al. (2002) Ghrelin and des-acyl ghrelin inhibit cell death in cardiomyocytes and endothelial cells through ERK1/2 and PI 3-kinase/AKT. J Cell Biol 159: 1029-1037.

18. Gualillo O, Caminos J, Blanco M, et al. (2001) Ghrelin, a novel placental-derived hormone. Endocrinology 142: 788-794.

19. Date Y, Nakazato M, Hashiguchi S, et al. (2002) Ghrelin is present in pancreatic $\alpha$-cells of humans and rats and stimulates insulin secretion. Diabetes 51: 124-129.

20. Mori K, Yoshimoto A, Takaya K, et al. (2000) Kidney produces a novel acylated peptide, ghrelin. FEBS Letters 486: 213-216.

21. Tena-Sempere M, Barreiro ML, Gonzalez LC, et al. (2002) Novel expression and functional role of ghrelin in rat testis. Endocrinology 143: 717-725.

22. Hattori N, Saito T, Yagyu T, et al. (2001) GH, GH receptor, GH secretagogue receptor and ghrelin expression in human T cells, B cells and neutrophils. J Clin Endocrinol Metab 86: 4284-4291.

23. Ghigo E, Arvat E, Giordano R, et al. (2001) Biologic activities of growth hormone secretagogues in humans. Endocrine 14: 87-93.

24. Broglio F, Benso A, Castiglioni C, et al. (2003) The endocrine response to ghrelin as a function of gender in humans in young and elderly subjects. J Clin Endocrinol Metab 88: 1537-1542.

25. Tscop M, Smiley DL, Heiman ML (2000) Ghrelin induces adiposity in rodents. Nature 407: 908-913.

26. Wren AM, Seal LJ, Cohen MA (2001) Ghrelin enhanc- 
es appetite and increases food intake in humans. J Clin Endocrinol Metab 86: 5992.

27. Frieboes RM, Murck H, Antonijevic IA, Steiger A (1999) Effects of growth hormone-releasing peptide6 on the nocturnal secretion of GH, ACTH and cortisol and on the sleep EEG in man: role of routes of administration. J Neuroendocrinol 11: 473-478.

28. Weikel JC, Wichniak A, Ising M, et al. (2003) Ghrelin promotes slow-wave sleep in humans. Am J PhysiolEndocrinol Metab 284: 407-415.

29. Asakawa A, Inui A, Kaga T, et al. (2001) A role of ghrelin in neuroendocrine and behavioral responses to stress in mice. Neuroendocrinology 74: 143-147.

30. Trudel L, Tomasetto C, Rio MC, et al. (2002) Ghrelin/ motilin-related peptide is a potent prokinetic to reverse gastric postoperative ileus in rat. Am J Physiol-Gastrointest Liver Physiol 282: 948-952.

31. Tschop M, Wawarta R, Riepl RL, et al. (2001) Postprandial decrease of circulating human ghrelin levels. $J$ Endocrinol Invest 24: 19-21.

32. Tolle V, Zizzari $\mathrm{P}$, Tomasetto $\mathrm{C}$, et al. (2001) In vivo and in vitro effects of ghrelin/motilin-related peptide on growth hormone secretion in the rat. Neuroendocrinology 73: 54-61.

33. Katugampola SD, Pallikaros Z, Davenport AP (2001) [25I-His (9)]-ghrelin, a novel radioligand for localizing GHS orphan receptors in human and rat tissue: upregulation of receptors with atherosclerosis. $\mathrm{Br} \mathrm{J}$ Pharmacol 134: 143-149.

34. Cassoni P, Papotti M, Ghe C, et al. (2001) Identification, characterization and biological activity of specific receptors for natural (ghrelin) and synthetic growth hormone secretagogues and analogs in human breast carcinomas and cell lines. J Clin Endocrinol Metab 86: 1738-1745.

35. Soriano-Guillen L, Barrios V, Chowen JA, et al. (2004) Ghrelin levels from fetal life through early adulthood: Relationship with endocrine and metabolic and anthropometric measures. J Pediatr 144: 30-35.

36. Sun Y, Ahmed S, Smith RG (2003) Deletion of ghrelin impairs neither growth nor appetite. Molec Cell Biol 23(22): 7973-7981.

37. Wortley KE, del Rincon JP, Murray JD, et al. (2005) Absence of ghrelin protects against early-onset obesity. 1: J Clin Invest 115(12): 3573-3578.

38. Van der Lely AJ, Tschöp M, Heiman ML, Ghigo E (2004) Biological, physiological, pathophysiological and pharmacological aspects of ghrelin. Endocr Rev 25: 426-457.

39. Gnanapavan S, Kola B, Bustin SA, et al. (2002) The tissue distribution of the mRNA of ghrelin and subtypes of its receptor, GHS-R, in humans. J Clin Endocrinol Metabol 87: 2988.

40. Muller EE, Rigamonti AE, De Giennaro Colonna V (2002) GH-related and extra-endocrine actions of
GH secretagogues in aging. Neurobiol Aging 23: $907-$ 919.

41. Takaya K, Ariyasu H, Kanamoto N, et al. (2000) Ghrelin strongly stimulates growth hormone release in humans. J Clin Endocrinol Metabol 85: 4908-4911.

42. Date Y, Murakami N, Toshinai K, et al. (2002) The role of the gastric afferent vagal nerve in ghrelininduced feeding and growth hormone secretion in rats. Gastroenterology 123: 1120-1128.

43. Casanueva FF, Dieguez C (2004) Ghrelin a new hormone muplicated in the regulation of $\mathrm{GH}$ secretion and body energy homeostasis. Growth, Genetics and Hormones 20: 1-8.

44. Kamegai J, Tamura H, Shimizu T, et al. (2004) The role of pituitary ghrelin in GH secretion: GHRHdependent regulation of pituitary ghrelin gene expression and peptide content. Endocrinology 145: 37313738 .

45. Popovic V, Miljic D, Micic D, et al. (2003) Ghrelin main action on the regulation of $\mathrm{GH}$ release is exerted at hypothalamic level. J Clin Endocrinol Metab 88: 3450-3453.

46. Yuxiang Sun, Pei Wang, Hui Zheng, and Roy G. Smith (2004) Ghrelin stimulation of growth hormone release and appetite is mediated through the growth hormone secretagogue receptor. Proc Natl Acad Sci USA 101: 4679-4684.

47. Zigman JM, Nakano Y, Coppari R, et al. (2005) Mice lacking ghrelin receptors resist the development of diet-induced obesity. J Clin Invest 115(12): 3564 3572 .

48. Barkan AL, Dimaraki EV, Jessup SK, et al. (2003) Ghrelin secretion in humans is sexually dimorphic, suppressed by somatostatin and not affected by the ambient growth hormone levels. J Clin Endocrinol Metabol 88: 2180-2184.

49. Smith RG, SunY, Betancourt L, Asnicar M (2004) Growth hormone secretagogues: prospects and potential pitfalls. Best Practice and Research-Clin Endocrinol Metabol 18: 333-347.

50. Freda PU, Reyes CM, Conwell IM, Sundeen RE, Wardlaw SL (2003) Serum ghrelin levels in acromegaly: effects of surgical and longacting octreotide therapy. $J$ Clin Endocrinol Metabol 88: 2037-2044.

51. Muccioli G, Tschop M, Papotti M, Deghenghi R, Heiman M, Ghigo E (2002) Neuroendocrine and peripheral activities of ghrelin: implications in metabolism and obesity. Eur J Pharmacol 440: 235-254.

52. Bowers CY (2001) Unnatural Growth Hormone - Releasing Peptide begets natural ghrelin. J Clin Endocrinol Metabol 86: 1464-1469.

53. Broglio F, Benso A, Giottero C (2002) Effects of glucose, free fatty acids or arginine load on the $\mathrm{GH}-$ releasing activity of ghrelin in humans. Clin Endocrinol (Oxf) 57: 265-271. 
54. Sun YK, Xi YP, Fenoglio CM, et al. (1984) The effect of age on the number of pituitary cells immunoreactive to growth hormone and prolactin. Hum Pathol 15: 169180.

55. Cappiello V, Ronchi C, Morpurgo PS, et al. (2002) Circulating ghrelin levels in basal conditions and during glucose tolerance test in acromegalic patients. Eur J Endocrinol 147: 189-194.

56. Popovic V (2005) Are there alternative tests for diagnosis of acromegaly? J Endocrinol Invest 28: 73-74.

57. Kozakowski J, Rabijewski M, Zgliczynski W (2005) Decrease in serum ghrelin levels in patients with acromegaly normalize after successful surgical treatment. Endokrynologia Polska 56: 862-870.

58. Wasko R, Jaskula M, Komarowska H (2006) Ghrelin concentrations in acromegalic patients in relation to the administered therapy. Neuro Endocrinol Lett 27: 162168.

59. Jarkovska Z, Rosicka M, Marek M, et al. (2006) Plasma levels of total and active ghrelin in acromegaly and growth hormone deficiency. Physiol Res 55: 175181.

60. Arosio M, Ronchi CL, Gebbia C (2004) Ghrelin administration affects circulating pituitary and gastroenteropancreatic hormones in acromegaly. Eur J Endocrinol 150: 27-32.

61. Norrelund H, Hansen TK, Orskov H (2002) Ghrelin immunoreactivity in human plasma is suppressed by somatostatin. Clin Endocrinol (Oxf) 57: 539-546.

62. Kohn DT, Kopchick JJ (2002) Growth hormone receptor antagonists. Review. Minerva Endocrinol 27: 287298.

63. Root AW, Root MJ (2002) Clinical pharmacology of human growth hormone and its secretagogues. Review. Cur Drug Targets-Immune, Endocr Metabol Disorders 2: 27-52.

64. Jorgensen JO, Feldt-Rasmussen U, Frystyk J (2005) Co-treatment of acromegaly with a somatostatin analog and a growth hormone receptor antagonist. J Clin Endocrinol Metabol 90: 5627-5631.

65. Stewart PM (2003) Pegvisomant: an advance in clinical efficacy in acromegaly. Eur J Endocrinol 148: 27-32.

66. Kopchick JJ, Parkinson C, Stevens EC, Traier PJ (2002) Growth hormone receptor antagonists: discovery, development and use in patients with acromegaly. Endocr Rev 23: 623-646.

67. Trainer PJ, Drake Wm, Katznelson L, et al. (2000) Treatment of acromegaly with the growth hormonereceptor antagonist pegvisomant. New Eng J Med 342: 1171-1177.

68. Paisley AN, Trainer P, Drake W (2004) Pegvisomant: a novel pharmacotherapy for the treatment of acromegaly. Exp Opin Biol Ther 4: 421-425.

69. Parkinson C, Trainer PJ (2001) The place of pegviso- mant in the management of acromegaly. Exp Opin Investigat Drugs 10: 1725-1735.

70. Colao A, Pivonello R, Auriemma RS (2006) Efficacy of 12-month treatment with the GH receptor antagonist pegvisomant in patients with acromegaly resistant to long-term, high-dose somatostatin analog treatment: effect on IGF-I levels, tumor mass, hypertension and glucose tolerance. Eur J Endocrinol 154: 467-477.

71. Biermasz NR, Van den Oever NC, Frolich M (2003) Sandostatin LAR in acromegaly: a 6-week injection interval suppresses GH secretion as effectively as a 4week interval. Clin Endocrinol (Oxf) 58: 288-295.

72. Chanson P, Boerlin V, Ajzenberg C (2000) Comparison of octreotide acetate LAR and lanreotide SR in patients with acromegaly. Clin Endocrinol (Oxf) 3: 577-586.

73. Karavitaki N, Botusan I, Radian S, Coculescu M, Turner HE, Wass JA (2005) The value of an acute octreotide suppression test in predicting long-term responses to depot somatostatin analogues in patients with active acromegaly. Clin Endocrinol (Oxf) 62: 282-288.

74. Pekic S, Doknic M, Miljic D, Joksimovic M (2006) Ghrelin test for the assessment of GH status in successfully treated patients with acromegaly. Eur J Endocrinol 154: 659-666.

75. Broglio F, Koetsveld PvP, Benso A (2002) Ghrelin secretion is inhibited by either somatostatin or cortistatin in humans. J Clin Endocrinol Metabol 87: 4829-4832.

76. Malik JA., English PJ, Gihatei MA, Bloom SR, MacFarlane JA, Wilding JP (2004) The relationship of ghrelin to biochemical and anthropometric markets of adult growth hormone deficiency. Clin Endocrinol (Oxf) 60: 137-141.

77. Giavoli C, Cappiello V, Corbetta S, et al. (2004) Different effects of short - and long - term recombinant $\mathrm{hGH}$ administration on ghrelin and adiponectin levels in GH-defecient adults. Clin Endocrinol (Oxf) 61: 8187.

78. Goldstone AP (2004) Prader-Willi syndrome: advances in genetics, pathophysiology and treatment. Trends Endocrinol Metabol 15(1): 12-20.

79. Haqq AM, Farooqi IS, O'Rahilly S, et al. (2003) Serum ghrelin levels are inversely correlated with body mass index, age, and insulin concentrations in normal children and are markedly increased in Prader-Willi syndrome. J Clin Endocrinol Metabol 88(1): 174-178.

80. DelParigi A, Tschop M, Heiman ML, et al. (2002) High circulating ghrelin: a potential cause for hyperphagia and obesity in prader-willi syndrome. $\mathrm{J}$ Clin Endocrinol Metabol 87(12): 5461-5464.

81. Bizzarri C, Rigamonti AE, Giannone G, Berardinelli R, Cella SG, Cappa M, Muller EE (2004) Maintenance of a normal meal-induced decrease in plasma ghrelin levels in children with Prader-Willi syndrome. Hormone 
Metabol Res 36(3): 164-169.

82. Ghigo E, Arvat E, Gianotti L, et al. (1994) Growth hormone-releasing activity of hexarelin, a new synthetic hexapeptide, after intravenous, subcutaneous, intranasal and oral administration in man. J Clin Endocrinol Metabol 78: 693-698.

83. Korbonits M, Kaltsas G, Perry L, et al. (1999) The growth hormone secretagogue Hexarelin stimulates the hypothalamo-pituitary-adrenal axis via arginine vasopressin. J Clin Endocrinol Metabol 84: 2489-2495.

84. Root AW, Root MJ (2002) Clinical pharmacology of human growth hormone and its secretagogues. Cur Drug Targets-Imm Endocr Metabol Disord 2: 27-52.

85. Wynne K, Stanley S, McGowan B, Bloom S (2005) Appetite control. J Endocrinol 184: 291-318.

86. Ariyasu H, Takaya K, Tagami T, et al. (2001) Plasma ghrelin levels are influenced by acute and chronic feeding states in humans. Proceedings of the 83rd Annual Meeting of the Endocrine Society, Denver, CO, pp. 336.

87. Lawrence CB, Snape AC, Baudoin FM, Luckman SM (2002) Acute central ghrelin and GH secretagogues induce feeding and activate brain appetite centers. Endocrinology 143(1): 155-162.

88. Cummings E, Purnell JQ, Frayo SR, Schmidova K, Wisse BE, Weigle DS (2001) A pre-prandial rise in plasma ghrelin levels suggests a role in meal initiation in humans. Diabetes 50: 1714-1719.

89. Shiiya T, Nakazato M, Mizuta M, et al. (2002) Plasma ghrelin levels in lean and obese humans and the effect of glucose on ghrelin secretion. J Clin Endocrinol Metabol 87: 240-244.

90. Guo ZF, Zheng X, Qin YW, Hu JQ, Chen SP, Zhang Z (2007) Circulating Preprandial Ghrelin to Obestatin Ratio Is Increased in Human Obesity. J Clin Endocrinol Metabol [Epub ahead of print].

91. Ahima RS, Osei SY (2001) Molecular regulation of eating behavior: new insights and prospects for therapeutic strategies. Trends Molec Med 7: 205-213.

92. Friedman JM, Halaas JL (1998) Leptin and the regulation of body weight in mammals. Nature 395: 763770.

93. Schwartz MW, Woods SC, Porte Jr D, Seeley RJ, Baskin DG (2000) Central nervous system control of food intake. Nature 404: 661-671.

94. Tschöp M, Weyer C, Tataranni PA, Devanarayan V, Ravussin E, Heiman ML (2001) Circulating ghrelin levels are decreased in human obesity. Diabetes 50: 707-709.

95. Ravussin E, Tschöp M, Heiman ML, Bouchard C (2001) Plasma ghrelin concentration and energy balance: overfeeding and negative energy balance studies in twins. J Clin Endocrinol Metabol 86: 4547-4551.

96. Yildiz BO, Suchard MA, Wong ML, McCann SM, Licinio J (2004) Alterations in the dynamics of circu- lating ghrelin, adiponectin and leptin in human obesity. Proc Natnl Acad Sci USA 101: 10434-10439.

97. Shiiya T, Nakazato M, Mizuta M, et al. (2002) Plasma ghrelin levels in lean and obese humans and the effect of glucose on ghrelin secretion. J Clin Endocrinol Metabol 87: 240-244.

98. Helmling S, Maasch C, Eulberg D, Buchner K (2004) Inhibition of ghrelin action in vitro and in vivo by an RNA-Spiegelmer. Proc Natnl Acad Sci USA 101: 13174-13179.

99. Zorrilla EP, Iwasaki S, Moss JA, et al. (2006) From the Cover: Vaccination against weight gain. Proc Natnl Acad Sci USA 103: 13226-13231.

100. Scacchi M, Pincelli AI, Cavagnini F (2003) Nutritional status in the neuroendocrine control of growth hormone secretion: the model of anorexia nervosa. Front Neuroendocrinol 24: 200-224.

101. Tanaka M, Naruo T, Yasuhara N, et al. (2003) Fasting plasma ghrelin levels in subtypes of anorexia nervosa. Psychoneuroendocrinology 28: 829-835.

102. Miljic D, Pekic S, Djurovic M, et al. (2006) Ghrelin has partial or no effect on appetite, growth hormone, prolactin and cortisol release in patients with anorexia nervosa. J Clin Endocrinol Metabol 91: 1491-1495.

103. Tanaka M, Naruo T, Muranaga T (2002) Increased fasting plasma ghrelin levels in patients with bulimia nervosa. Eur J Endocrinol 146(6): R1-3.

104. Troisi A, Di Lorenzo G, Lega I, et al. (2005) Plasma ghrelin in anorexia, bulimia, and binge-eating disorder: relations with eating patterns and circulating concentrations of cortisol and thyroid hormones. Neuroendocrinology 81(4): 259-266.

105. Tanaka M, Naruo T, Nagai N, et al. (2003) Habitual binge/purge behavior influences circulating ghrelin levels in eating disorders. J Psych Res 37(1): 17-22.

106. Dardennes RM, Zizzari P, Tolle V, et al. (2006) Family trios analysis of common polymorphisms in the obestatin/ghrelin, BDNF and AGRP genes in patients with Anorexia nervosa: Association with subtype, bodymass index, severity and age of onset. Psychoneuroendocrinology. [Epub ahead of print].

107. Monteleone P, Tortorella A, Castaldo E, Di Filippo C, Maj M (2007) The Leu72-Met polymorphism of the ghrelin gene is significantly associated with binge eating disorder. Psych Gen 17(1): 13-16.

108. Ando T, Komaki G, Naruo T, et al. (2006) Possible role of preproghrelin gene polymorphisms in susceptibility to bulimia nervosa. 1: Am J Med Gen. Part B, Neuropsychiatric Genetics 141(8): 929-934.

109. Monteleone P, Tortorella A, Castaldo E, Di Filippo C, Maj M (2006) No association of the Arg51Gln and Leu72Met polymorphisms of the ghrelin gene with anorexia nervosa or bulimia nervosa. Neurosci Lett 398(3): 325-327.

110. Adeghate E, Ponery AS (2002) Ghrelin stimulates 
insulin secretion from the pancreas of normal and diabetic rats. J Neuroendocrinol 14: 555-560.

111. Lee HM, Wang G, Englander EW, Kojima M, Greeley GH Jr (2002) Ghrelin, a new gastrointestinal endocrine peptide that stimulates insulin secretion: enteric distribution, ontogeny, influence of endocrine and dietary manipulations. Endocrinology 143: 185-190.

112. Egido EM, Rodriguez-Gallardo J, Silvestre RA, Marco J (2002) Inhibitory effect of ghrelin on insulin and pancreatic somatostatin secretion. Eur J Endocrinol 146: 241-244.

113. Kvist Reimer M, Pacini G, Ahren B., et al. (2003) Dose-dependent inhibition by ghrelin of insulin secretion in mouse. Endocrinology 144: 916-921.

114. Saad MF, Bernaba B, Hwu CM, Jinagouda S, Fahmi S, Kogosov E, Boyadjian R (2002) Insulin regulates plasma ghrelin concentration. J Clin Endocrinol Metabol 87: 3997-4000.

115. Ariyasu H, Takaya K, Tagami T, et al. (2001) Stomach is a major source of circulating ghrelin and feeding state determines plasma ghrelin-like immunoreactivity levels in humans. J Clin Endocrinol Metabol 86: 47534758.

116. Broglio F, Gottero C, Benso A, et al. (2003) Effects of ghrelin on the insulin and glycemic responses to glucose, arginine or free fatty acids load in humans. $J$ Clin Endocrinol Metabol 88: 4268-4272.

117. Caixas A, Bashore C, Nash W, Pi-Sunyer F, Laferrere B (2002) Insulin, unlike food intake, does not suppress ghrelin in human subjects. J Clin Endocrinol Metabol 87: 1902.

118. Soriano-Guillen L, Barrios V, Lechuga-Sancho A, Chowen JA, Argente J (2004) Response of circulating ghrelin levels to insulin therapy in children with newly diagnosed type 1diabetes mellitus. Pediatr Res 55: 830-835.

119. Murdolo G, Lucidi P, Di Loreto C, et al. (2003) Insulin is required for prandial ghrelin suppression in humans. Diabetes 52: 2923-2927.

120. Poykko SM, Kellokoski E, Horkko S, Kauma H, Kesaniemi YA, Ukkola O (2003) Low plasma ghrelin is associated with insulin resistance, hypertension and the prevalence of type 2 diabetes. Diabetes 52: $2546-$ 2553.

121. Erdmann J, Lippl F, Wagenpfeil S, Schusdiarra V (2005) Differential association of basal and postprandial plasma ghrelin with leptin, insulin and type 2 diabetes. Diabetes 54: 1371-1378.

122. Sun Y, Asnicar M, Saha PK, Chan L, Smith RG (2006) Ablation of ghrelin improves the diabetic but not obese phenotype of ob/ob mice. Cell Metabol 3(5): 379-386.

123. Frascarelli S, Ghelardoni S, Ronca-Testoni S, Zucchi R (2003) Effect of ghrelin and synthetic growth hormone secretagogues in normal and ischemic rat heart. Basic Res Cardiol 98: 401-405.
124. Li L, Zhang LK, Pang YZ, et al. (2006) Cardioprotective effects of ghrelin and des-octanoyl ghrelin on myocardial injury induced by isoproterenol in rats. Acta Pharmacol Sinica 27: 527-535.

125. Chang L, Zhao J, Li GZ, Geng B, Pan CS, Qi YF, Tanh CS (2004) Ghrelin protects myocardium from isoproterenol-induced injury in rats. Acta Pharmacol Sinica 25: 1131-1137.

126. Bedendi I, Alloatti G, Marcantoni A, et al. (2003) Cardiac effects of ghrelin and its endogenous derivatives des-octanoyl ghrelin and des-Gln 14-ghrelin. Eur $J$ Pharmacol 476: 87-95.

127. Nagaya N, Uematsu M, Kojima M, et al. (2001) Chronic administration of ghrelin improves left ventricular dysfunction and attenuates development of cardiac cachexia in rats with heart failure. Circulation 104: 1430-1435.

128. Nagaya N, Kaugawa K (2003) Ghrelin, a novel growth hormone-releasing peptide, in the treatment of chronic heart failure. Inv Rev Regul Peptides 114: 71-77.

129. Kleinz MJ, Maguire JJ, Skepper JN, Davenport AP (2006) Functional and immunocytochemicalevidence for a role of ghrelin and des-octanoyl ghrelin in the regulation of vascular tone in man. Cardiovasc Res 69: 227-235.

130. Nagaya N, Kojima M, Uematsu M, et al. (2001) Hemodynamic and hormonal effects of human ghrelin in healthy volunteers. Am J Physiol-Regulatory, Integrative, Comparative Physiology 208: 1483-1487.

131. Enomoto M, Nagaya N, Uematsu M, et al. (2003) Cardiovascular and hormonal effects of subcutaneous administration of ghrelin, a novel growth hormonereleasing peptide in healthy humans. Clin Sci (Lond) 105: 431-435.

132. Nagaya N, Uematsu M, Kojima M, et al. (2001) Elevated circulating level of ghrelin in cachexia associated with chronic heart failure: relationships between ghrelin and anabolic/catabolic factors. Circulation 104: 2034-2038.

133. Nagaya N, Miyatake K, Uematsu M, et al. (2001) Hemodynamic, renal and hormonal effects of ghrelin infusion in patients with chronic heart failure. J Clin Endocrinol Metabol 86: 5854-5859.

134. Nagaya N, Moriya J, Yasumura Y, et al. (2004) Effects of ghrelin administration on left ventricular function, exercise capacity and muscle wasting in patients with chronic heart failure. Circulation 110: 3674-3679.

135. Nagaya N, Kangawa K (2006) Therapeutic potential of ghrelin in the treatment of heart failure. Drugs 66: 439448.

136. Tacke F, Brabant G, Kruck E, et al. (2003) Ghrelin in chronic liver disease. J Hepatol 38: 447-454.

137. Marchesini G, Pagotto U, Bugianesi E, et al. (2003) Low ghrelin concentrations in nonalcoholic fatty liver disease are related to insulin resistance. J Clin Endo- 
crinol Metabol 88: 5674-5679.

138. Murata M, Okimura Y, Lida K, et al. (2002) Ghrelin modulates the downstream molecules of insulin signalling in hepatoma cells. J Bioll Chem 277: 5667-5674.

139. Sajjad A, Mottershead M, Syn WK, Jones R, Smith S, Nwokolo CU (2005) Ciprofloxacin suppresses bacterial overgrowth, increases fasting insulin but does not correct low acylated ghrelin concentrations in nonalcoholic steatohepatitis. Alim Pharmacol Ther 22: 291-299.

140. Yoshimoto A, Mori K, Sugawara A, et al. (2002) Plasma ghrelin and desacyl ghrelin concentrations in renal failure. J Am Soc Nephrol 13: 2748-2752.

141. Ayala ER, Pecoits-Filho R, Heimburger O, Lindholm B, Norfors L, Stenvinkel P (2004) Associations between plasma ghrelin levels and body composition in end-stage renal disease: a longitudinal study. Nephrol, Dialysis Transpl 19: 421-426.

142. Guebre-Egziabher F, Bernhard J, Geelen G, Malvoisin E, Hadj-Aissa A, Fouque D (2005) Leptin, adiponectin, and ghrelin dysregulation in chronic kidney disease. $J$ Renal Nutr 15(1): 116-120.

143. Yabuki A, Taharaguchi S, Ichii O, Kojima M, Nishi Y, Mifune H, Kamimura R, Matsumoto M, Suzuki S (2006) Immunohistochemical localization of ghrelin in rodent kidneys. Histochemistry and Cell Biology 126(2): 231-238.

144. Inglesias P, Diez JI, Fernantez-Reyes MJ, et al. (2006) Serum ghrelin concentrations in patients with renal failure undergoing dialysis. Clin Endocrinol (Oxf) 64: 68.

145. Cugini P, Paggi A, Cristina G, et al. (1999) Hunger sensation in Graves' disease before and after pharmacological therapy. La Clinica Terapeutica 150: 115119.

146. Dalkjaer Riis AL, Hansen TK, Moller N, Weeke J, Otto J, Jorgensen L (2003) Hyperthyroidism is associated with suppressed circulating ghrelin levels. J Clin Endocrinol Metabol 88: 853-857.

147. Gimenez-Palop O, Gimenez-Perez G, Mauricio D, et al. (2005) Circulating ghrelin in thyroid dysfunction is related to insulin resistance and not to hunger, food intake or anthropometric changes. Eur $J$ Endocrinol 153: 73-79.

148. Caminos JE, Seoane LM, Tovar SA, Casanueva FF, Dieguez C (2002) Influence of thyroid status and growth hormone deficiency on ghrelin. Eur J Endocrinol 147: 159-163.

149. Volante M, Allia E, Fulcheri E, Cassoni P, Ghigo E, Muccioli C, Papotti M (2003) Ghrelin in fetal thyroid and follicular tumors and cell lines. Am J Pathol 162: 645-654.

150. Adami GF, Cordera R, Marinari G, Lamerini G, Andraghetti G, Scopinaro N (2003) Plasma ghrelin concentration in the short-term following biliopancre- atic diversion. Obesity Surgery 13: 889-892.

151. Adami GF, Cordera R, Andraghetti G, Camerini GB, Marinari GM, Scopinaro N (2004) Changes in serum ghrelin concetration following biliopancreatic diversion for obesity. Obesity Res 12: 684-687.

152. Holdstock C, Engstrom BE, Ohrvall M, Lind L, Sunbom M, Karlsson FA (2003) Ghrelin and adipose tissue regulatory peptides: effect of gastric bypass surgery in obese humans. J Clin Endocrinol Metabol 88: 3177-3183.

153. Tritos NA, Mun E, Bertkau A, Grayson R, MaratosFlier E, Goldfine A (2003) Serum ghrelin levels in response to glucose load in obese subjects post-gastric bypass surgery. Obesity Res 11: 919-924.

154. Geloneze B, Tambascia MA, Pilla VF, Geloneze SR, Repetto EM, Pareja JC (2003) Ghrelin: a gut-brain hormone: effect of gastric bypass surgery. Obesity Surgery 13: $17-22$.

155. Stoeckli R, Chanda R, Langer I, Keller U (2004) Changes of body weight and plasma ghrelin levels after gastric banding and gastric bypass. Obesity Res 12: 346-350.

156. Leonetti F, Silecchia G, Iacobellis G, et al. (2003) Different plasma ghrelin levels after laparoscopic gastric bypass and adjustable gastric banding in morbid obese subjects. J Clin Endocrinol Metabol 88: 4227-4231.

157. Cummings DE, Weigle DS, Frayo RS, Breen PA, Dellinger EP, Purnell JQ (2002) Plasma ghrelin levels after diet-induced weight loss or gastric bypass surgery. New Eng J Med 346: 1623-1630.

158. Fernandez-Santiago R, Dominguez-Diez A, VazquezSalvi L, Fernandez-Escalante JC, Amado JA (2005) Fasting plasma ghrelin levels increase progressively after biliopancreatic diversion: one-year follow-up. Obesity Surgery 15: 187-190.

159. Cassoni P, Ghe C, Marrocco T, et al. (2004) Expression of ghrelin and biological activity of specific receptors for ghrelin and des-acyl ghrelin in human prostate neoplasm and related cell lines. Eur J Endocrinol 150: 173-184.

160. Jeffery PL, Herington AC, Chopin LK (2003) The potential autocrine/paracrine roles of ghrelin and its receptor in hormone-dependent cancer. Cytokine \& Growth Factor Rev 14: 113-122.

161. Gaytan F, Barreiro ML, Caminos JE, et al. (2004) Expression of ghrelin and its functional receptor, the type 1a growth hormone secretagogue receptor, in normal human testis and testicular tumors. J Clin Endocrinol Metabol 89: 400-409.

162. Papotti M, Cassoni P, Volante M, Deghenghi R, Muccioli G, Chigo E (2001) Ghrelin-producing endocrine tumors of the stomach and indestine. J Clin Endocrinol Metabol 86: 5052-5059.

163. Rindi G, Savio A, Torsello A, et al. (2002) Ghrelin expression in gut endocrine growths. Histochem Cell Biol 
117: 521-525.

164. Duxbury MS, Waseem T, Ho H, Robinson MK, Zinner MJ, Ashley SW, Whang EE (2003) Ghrelin promotes pancreatic adenocarcinoma cellular proliferation and invasiveness. Biochem Biophys Res Commun 309: 464468.

165. Murata M, Okimura Y, Iida K, et al. (2001) Ghrelin modulates the downstream molecules of insulin signaling in hepatoma cells. $J$ Biochem 277: 5667-5674.

166. Korbonits M, Bustin SA, Kojima M, et al. (2001) The expression of the growth hormone secretagogue receptor ligand ghrelin in normal and human pituitary and other neuroendocrine tumors. J Clin Endocrinol Metabol 86: 881-887.

167. Hubina E, Ruscica M, Nanzer AM, Czirjak S, Goth MI, Grossman AB, Korbonits M (2005) Novel molecular aspects of pituitary adenomas. $J$ Endocrinol Invest 28: 87-92.

168. Hoshino R, Chatani Y, Yamori T (1999) Constitutive activation of the 41-/43-kDa mitogen-activated protein kinase signalling pathway in human tumors. Oncogene
18: 813-822.

169. Volante M, Allia E, Fulcheri E, Cassoni P, Chigs E, Muccidi G, Papotti M (2003) Ghrelin in fetal thyroid and follicular tumors and cell lines: expression and effects on tumor growth. Am J Pathol 162: 645-654.

170. Kanamoto N, Akamizu T, Hosoda H, et al. (2001) Substantial production of ghrelin by a human medullary thyroid carcinoma cell line. J Clin Endocrinol Metabol 86: 4984-4990.

171. Cassoni P, Papotti M, Catapano F, Deghenhi R, Chigo E, Muccidi G (2000) Specific binding sites for synthetic growth hormone secretagogues in non-tumoral and neoplastic human thyroid tissue. $J$ Endocrinol 165: 139-146.

172. Shimizu $Y$, Nagaya N, Isobe T, Imazu M, Okumura $H$, Hosoda H, Kojima M, Kangawa K, Kohno N (2003) Increased plasma ghrelin level in lung cancer lachexia. Clin Cancer Res 9: 774-778.

173. Hanada T, Toshinai K, Date Y, et al. (2004) Upregulation of ghrelin expression in cachetic nude mice bearing human melanoma cells. Metabolism 53: 84-88. 